\title{
A CASE OF EPITHELIAL ADRENAL GLAND CYST
}

\author{
Vujicik Ivo \\ University Clinic for Urology, University Clinical Centre „Mother Theresa“, \\ Skopje, Republic of North Macedonia
}

Primljen/Received 28. 07. 2019. god.

Abstract: Introduction: Adrenal gland cysts are relatively rare cystic lesions, which are usually discovered incidentally with the widespread use of radiological imaging techniques.

Case report: We reported a clinical case of a 36-year-old woman who presented with a 6 months history of right flank discomfort. The contrast-enhanced abdominal computed tomography revealed a well-circumscribed cystic lesion with a capsule in the Morrison's pouch measuring 57 x $51 \mathrm{~mm}$. On abdominal magnetic resonance imagining (MRI), the cystic lesion exhibited a hypointensity on T-1 weighted images and hyperintensity on T-2 weighted images. Surgery was decided because of lesion size and doubts concerning its etiology. The final histopathological diagnosis was an epithelial cyst of the adrenal gland.

In summary, epithelial adrenal cysts are uncommon retroperitoneal lesions. In our case, open adrenalectomy was performed and the prognosis was excellent.

Key words: Adrenal, epithelial cyst, adrenal lesion, adrenal gland.

\section{INTRODUCTION}

Adrenal gland cysts are relatively rare cystic lesions, which are usually discovered incidentally with the widespread use of radiological imaging techniques. However, they may be presented with flank pain or gastrointestinal symptoms.

Cysts of the adrenal gland have been categorized into four subtypes by origin: pseudocysts, endothelial cysts, epithelial cysts and parasitic cysts (1). Epithelial cysts of the adrenal gland are uncommon accounting for only $9 \%$ of all adrenal cysts (2). Although adrenal cysts are benign in nature, some pieces of literature indicate that some cysts may be malignant with an incidence of $7 \%$ (3).

\section{CASE REPORT}

We reported a clinical case of a 36-year-old woman who presented with a 6 months history of right
Prihvaćen/Accepted 10. 10. 2019. god.

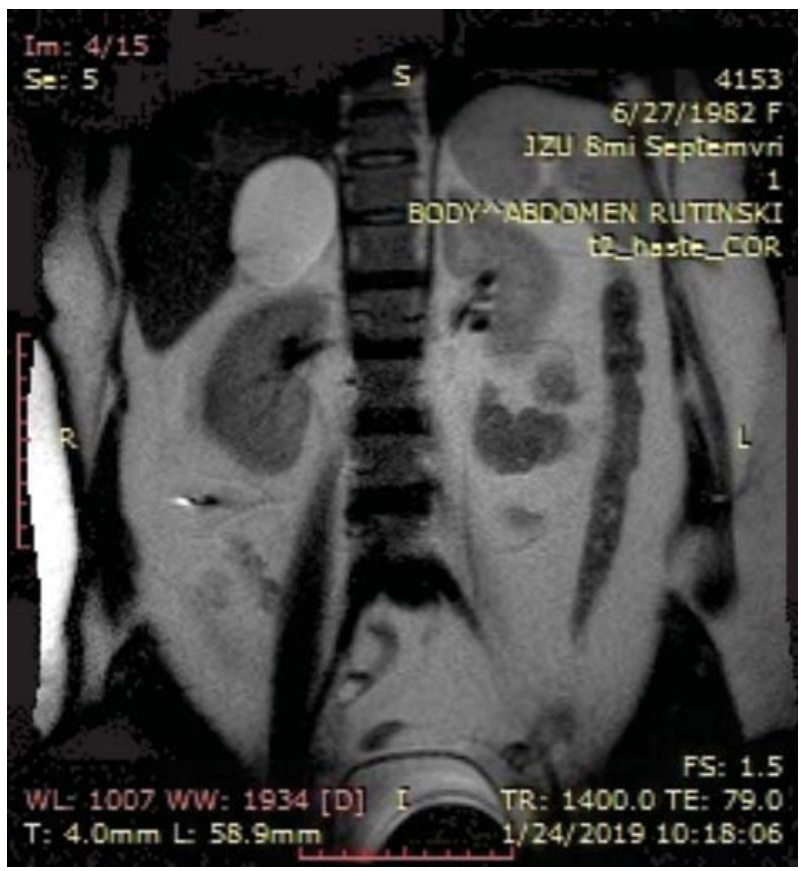

Figure 1. MRI of the right adrenal cystic lesion

flank discomfort. Physical examination did not reveal any abnormalities. The contrast-enhanced abdominal computed tomography revealed a well-circumscribed cystic lesion with a capsule in the Morrison's pouch measuring 57 x $51 \mathrm{~mm}$. On abdominal magnetic resonance imagining (MRI), the cystic lesion exhibited a hypointensity on T-1 weighted images and hyperintensity on T-2 weighted images (Figure 1). On admission, all laboratory examinations and adrenal-related hormones in the patient were in the reference range, so we ruled out any adrenal endocrine dysfunction. Surgery was decided because of lesion size and doubts concerning its etiology. An uncomplicated transabdominal right adrenalectomy was performed. She was discharged on the sixth postoperative day. The gross pathological examination revealed cystic lesion with dimensions $7 \times 6 \times 4 \mathrm{~cm}$, weighting $116 \mathrm{~g}$ with the attached ad- 
renal gland. On microscopical examination, the cyst had a thin wall composed of collagenous tissue lined by cuboidal cells. Immunohystochemically, the cyst lining was positive for CKAE1/A3. The final histopathological diagnosis was an epithelial cyst of the adrenal gland.

\section{DISCUSSION}

Adrenal gland cysts are usually unilateral and commonly appear in the third and sixth decade of life (1). The male to female ratio is $1: 3$ (1). Most of them are asymptomatic lesions but when they have a large size, the symptoms include abdominal or flank pain and gastrointestinal symptoms. Rarely they can be presented with hypovolemic shock caused by bleeding inside the cyst (4) or sepsis caused by infection of a pseudocyst (5).

The majority of adrenal cystic lesions are asymptomatic and endocrine nonactive and may be incidentally detected by radiographic techniques (ultrasound, computed tomography, and magnetic resonance). An ultrasonographic finding of adrenal cysts includes well marginated, anechogenic lesions (6). CT scans demonstrate hypodense, non-enhancing masses (7). Abdominal MRI may show a hypointensity on T-1 weighted images and a hyperintensity on T-2 weighted images (7).

Adrenal gland cysts are classified in 1966 by Foster into four groups by histological type: endothelial, epithelial, pseudocysts and parasitic cysts. The epithelial cysts have been subdivided upon purpose into four groups: glandular or retention cysts, cystic adenomas and embryonal cysts (1). Microscopically, the epithelial cysts are lined by a single layer of cytokeratin positive cells.

Main indications for surgical excision of this adrenal cystic lesions are to relieve mass effect symptoms, to remove endocrine active adrenal cysts, to exclude malignancy and to treat complications. For adrenal cysts larger than $3.5 \mathrm{~cm}$ aspiration of adrenal cysts is recommended. Conservative management is indicated for small asymptomatic endocrine no active cysts smaller than $6 \mathrm{~cm}$ with aspiration only and follow up with interval CT scans (5).

In summary, epithelial adrenal cysts are uncommon retroperitoneal lesions. In our case, open adrenalectomy was performed and the prognosis was excellent.

\section{Abbreviations \\ CT - computed tomography \\ MRI - magnetic resonance imaging}

Conflict of Interests: The authors declare that there are no conflicts of interest related to this article.

Funding: None

\section{Licensing}

This work is licensed under a Creative Commons Attribution 4.0 International (CC BY 4.0) License.

\section{Sažetak}

\section{PRIKAZ SLUČAJ EPITELIJALNE NADBUBREŽNE CISTE Vujicik Ivo \\ University Clinic for Urology, University Clinical Centre "Mother Theresa", Skopje, Republic of North Macedonia}

Uvod: Ciste nadbubrežne žlezde su relativno retke cistične lezije, koje se obično otkrivaju slučajno zbog široke primene radioloških tehnika.

Prikaz slučaja: Prikazujemo slučaj žene, 36 godina starosti, koja je imala 6 . mesečnu istoriju osećaja nelagodnosti u desnom lumbalnom predelu. Kontrasna tomografija abdomena otkrila je dobro ograničenu inkapsuliranu cističnu leziju u Morisonovom prostoru, dimenzija 57 x $51 \mathrm{~mm}$. Na magnetnoj rezonanci abdomena cistična lezija se prikazala sa hiposignalom na
T-1 slikama i hipersignalom na T-2 slikama. Urađena je hirurška ekscizija lezije zbog njene veličine i sumnjive etiologije. Konačna histopatološka dijagnoza bila je epitelna cista nadbubrežne žlezde.

Ukratko, epitelne ciste adrenalnih žlezda su retke retroperoperitonelne lezije. U našem slučaju, urađena je otvorena adrenalektomija sa odličnom prognozom.

Ključne reči: nadbubreg, epitelna cista, nadbubrežna lezija, nadbubrežna žlezda. 


\section{REFERENCES}

1. Ali Z, Tariq H, Rehman U. Endothelial cysts of adrenal gland. J Coll Physicians Surg Pak. 2019; 29(6): 16-7.

2. Limaiem F, Korbi S, Jedidi S, Aloui S, Hassen F, Arfa N et al. Adrenal epithelial cyst: a case report. Pathologica. 2012; 104(2): 82-4.

3. Subbaro C, Yogesh B, Malakondareddy K. Giant adrenal cyst displacing the right kidney. Indian J Urol. 2016; 32(1): $81-2$.

\section{Correspondence to/Autor za korespondenciju:}

\section{Ivo Vujicik}

University Clinic for Urology,

University Clinical Centre "Mother Theresa", Skopje, Republic of North Macedonia

Ul. Majka Tereza 17, 1000 Skopje.

Tel. +38971269945.

E-mail: ivovujicic@yahoo.com
4. Richa R, Devajit N, Sudheer A. Vascular cyst of adrenal: a report of two cases. Ind J Vasc Endovasc Surg. 2016; 3(2): 75-6.

5. Atim T, Mukhtar A. Giant adrenal cyst in a young female patient: a case report. Afr J Urol.2016; 22(2): 83-5.

6. Jin Fan J, Jie Tang J, Jiabin Fang J, He E, Li J, Li Q et al. Ultrasound imagining in the diagnosis of bening and suspicious adrenal lesions. Med Sci Monit. 2014; 20: 2132-41.

7. Wang F, Lui J, Zhang R, Bai Y, Li C, Li B et al. CT and MRI of adrenal gland pathologies. Quant Imaginig Med Surg. 2018; 8(8): 853-7. 